\section{Nodulation of Seaside Alder Topdressed with Controlled-release Fertilizer}

\author{
Taun Beddes ${ }^{1}$ and Heidi A. Kratsch ${ }^{2}$
}

\begin{abstract}
AdDITIONAL INDEX WORDs. Alnus maritima, actinorhizal, sustainable nursery production, root nodules, nitrogen-use efficiency

SUMMARY. Seaside alder (Alnus maritima) is a rare species adapted for ornamental use. It can be produced easily by commercial growers, and when soil-inoculated in nursery containers, will form root nodules containing nitrogen ( $N$ )-fixing bacteria in the genus Frankia. It has been demonstrated that nodulation within this species can be controlled by the amount of $\mathrm{N}$ plants receive from a liquid source; however, granular controlled-release fertilizers (CRF) also are commonly used by commercial growers, and information is not available on CRF effects on nodulation. We sought to determine the application rate of CRF that will maximize nodulation of seaside alder while sustaining acceptable plant health and growth. Inoculated containerized plants were topdressed with CRF at eight application rates from 0 to $32.0 \mathrm{~g}$ per container. A control group of uninoculated plants received the manufacturer's prescribed rate of $6.0 \mathrm{~g}$ per 6 -inch-diameter standard round pot. Regression analysis revealed that treatment with $2.0 \mathrm{~g}$ of CRF maximized root nodule formation (a mean of 26 nodules), while nodulation was inhibited at CRF rates $\geq 4.0$ g. Plant growth parameters and leaf $\mathrm{N}$ content of inoculated plants treated with $2.0 \mathrm{~g}$ of CRF were similar to those of uninoculated plants receiving the prescribed rate of CRF $(P<0.05)$; nitrate-nitrogen leaching from pots containing 2.0-g CRF-treated plants was minimal. We conclude that vigorous nodulated plants of seaside alder can be produced, with minimal nitrate leaching, by providing CRF at lower than prescribed rates.
\end{abstract}

S easide alder is a threatened species native to the United States in Georgia, Oklahoma, and along the Delmarva Peninsula in Delaware and Maryland (Schrader and Graves, 2000a). Efforts have been made to encourage its use by the nursery industry because it has been found to be well suited for landscape use (Graves and Schrader, 2004; Kratsch, 2008), and can be propagated readily from cuttings or seed (Schrader and Graves, 2000a, 2000b). Plants of seaside alder have the capacity to fix atmospheric nitrogen (N) by way of a relationship with Frankia bacteria, which colonize root nodules (Stibolt, 1978). Such N-fixing species can survive, and often thrive, in $\mathrm{N}$-poor soils in the wild (Paschke, 1997); in cultivated situations, they can add significant

Department of Plants, Soils, and Climate, Utah State University, 4820 Old Main Hill, Logan, UT 84322

This research was supported by the Utah Agricultural Experiment Station, Utah State University.

This article is a portion of a thesis submitted by Taun Beddes in partial fulfillment of requirements for a master's degree.

We thank James A. Schrader and William R. Graves for their donation of seed.

${ }^{1}$ Current address: Cache County Extension, Utah State University, 179 North Main Street, Logan, UT 84321.

${ }^{2}$ Corresponding author. E-mail: kratschh@unce.unr. edu.
$\mathrm{N}$ to the soil environment (Hansen and Dawson, 1982).

Nursery production of nodulated plants could be potentially valuable because nodulated $\mathrm{N}$-fixing plants might perform better than non-N-fixing taxa in landscape situations as a result of their capacity to thrive in N-deficient soils. Furthermore, the presence of nodules on nursery plants could allow for reduction in $\mathrm{N}$-fertilizer use and more efficient use of applied N. Sellstedt and Huss-Danell (1986) found that nodulated gray alder (Alnus incana) used $\mathrm{N}$ more efficiently than did non-nodulated gray alder receiving ammonium nitrate $\left(\mathrm{NH}_{4} \mathrm{NO}_{3}\right)$ in aqueous solution as its $\mathrm{N}$ source. Nursery growers view nitrate-N $\left(\mathrm{NO}_{3}-\mathrm{N}\right)$ contamination of groundwater as one of the major challenges for sustainable production (Urbano, 1989). The use of controlled-release fertilizers (CRF) for crop fertilization has been touted as a means to reduce $\mathrm{NO}_{3}-\mathrm{N}$ leaching from containerized nursery crops (Colangelo and Brand, 2001), and CRF is now widely used in nursery production. However, no studies have investigated effects of CRF on nodule formation in $\mathrm{N}$-fixing plants.

It has been demonstrated with various actinorhizal species that nodulation can be limited when plant roots are exposed to high concentrations of $\mathrm{N}$ in aqueous solution (Berry and Torrey, 1985; Gentili and HussDanell, 2003; Kohls and Baker, 1989; Martin et al., 2003; Thomas and Berry, 1989). Laws and Graves (2005) investigated the dynamics of this response in seaside alder, and demonstrated $\mathrm{N}$-induced inhibition of nodulation and nodule activity, which was rapidly reversible after removal of $\mathrm{N}$ from the fertilizer solution. This is useful information for nurseries desiring to produce nodulated plants because inadvertent, short-term exposure to high $\mathrm{N}$ does not destroy the $\mathrm{N}$-fixing capacity of seaside alder (Laws and Graves, 2005).

Our objectives were to examine how $\mathrm{NH}_{4} \mathrm{NO}_{3}$ delivered in a controlled-release form would influence nodulation in seaside alder, and to determine the level of CRF that would enhance nodule formation while sustaining acceptable plant health and growth and minimizing $\mathrm{NO}_{3}-\mathrm{N}$ leaching from containers. Our results will provide growers who rely on CRF for delivery of plant nutrients with guidelines for their use with nodulated seaside alder.

\section{Materials and methods}

In Mar. 2007, seeds of seaside alder from a population in Oklahoma (Schrader and Graves, 2000b) were rinsed with distilled water and were cold-stratified between moist filter

\begin{tabular}{llll}
\hline $\begin{array}{l}\text { Units } \\
\begin{array}{l}\text { To convert U.S. to SI, } \\
\text { multiply by }\end{array}\end{array}$ & U.S. unit & SI unit & $\begin{array}{l}\text { To convert SI to U.S., } \\
\text { multiply by }\end{array}$ \\
\hline 29.5735 & $\mathrm{fl} \mathrm{oz}$ & $\mathrm{mL}$ & 0.0338 \\
2.54 & inch(es) & $\mathrm{cm}$ & 0.3937 \\
6.4516 & inch $^{2}$ & $\mathrm{~cm}^{2}$ & 0.1550 \\
16.3871 & inch $^{3}$ & $\mathrm{~cm}^{3}$ & 0.0610 \\
28.3495 & $\mathrm{oz}$ & $\mathrm{g}$ & 0.0353 \\
28,350 & $\mathrm{Oz}$ & $\mathrm{mg}$ & $3.5274 \times 10^{-5}$ \\
$\left({ }^{\circ} \mathrm{F}-32\right) \div 1.8$ & ${ }^{\circ} \mathrm{F}$ & ${ }^{\circ} \mathrm{C}$ & $\left(1.8 \times{ }^{\circ} \mathrm{C}\right)+32$
\end{tabular}


papers in sealed petri dishes at $4{ }^{\circ} \mathrm{C}$ for 8 weeks. Stratified seeds were sown in a seed flat (volume $=8586 \mathrm{~cm}^{3}$ ) filled with Mix \#3 Germinating (Sun-Gro, Bellevue, WA) and were germinated on a greenhouse misting bench where 16-h photoperiods were provided by using 400-W, high-pressure sodium lamps. Three weeks after germination, seedlings were transplanted into individual plastic pots (volume $=235$ $\mathrm{cm}^{3}$ ) containing an unpasteurized growing substrate composed of 1 sphagnum peatmoss:1 perlite (by volume). Plants were irrigated with tap water daily and were fertilized three times weekly with $15 \mathrm{~N}-2.9 \mathrm{P}-$ 12.5K water-soluble fertilizer (Peter's Cal-Mag $^{\text {TM}}$; Scotts-Sierra, Marysville, $\mathrm{OH}$ ) adjusted to $\mathrm{pH} 5.5$, and containing $21 \mathrm{~mm} \mathrm{~N}$ to prevent nodulation before treatments began. Mean greenhouse air temperature was $25.5 / 20{ }^{\circ} \mathrm{C}$ (day/night), with a daily mean of $22^{\circ} \mathrm{C}$. Mean temperature of container substrate was $27 / 22{ }^{\circ} \mathrm{C}$ (day/night). Mean relative humidity was $52 \%$, and mean photosynthetically active radiation $(P A R)$ during the experiment was $646 \mu \mathrm{mol} \cdot \mathrm{m}^{-2} \cdot \mathrm{s}^{-1}$.

On 1 Aug. 2007, fertilization was discontinued. Forty-eight 3month-old seedlings of consistent size were selected, and the growing substrate was washed from the roots to confirm that they had not formed nodules. The seedlings were transplanted into square plastic pots (volume $=2200 \mathrm{~cm}^{3}$ ) containing the growing substrate previously reported. On 15 Aug. 2007, seedlings were assigned randomly to one of 12 groups, and each plant was treated as an experimental unit $(\mathrm{n}=4)$. Group 1 was destructively harvested at the start of the experiment for baseline measurements of plant growth parameters. The remaining plants were arranged on a greenhouse bench in a randomized complete block design. Each of nine groups was topdressed with 0 , $0.5,1.0,2.0,4.0,6.0,8.0,16.0$, or $32.0 \mathrm{~g}$ of $15 \mathrm{~N}-3.9 \mathrm{P}-10 \mathrm{~K}$ CRF [Osmocote Plus ${ }^{\text {TM}}$; Scotts-Sierra (hereafter referred to as CRF)] formulated to have a 3- to 4-month release rate at $21^{\circ} \mathrm{C}$, and containing micronutrients. Group 11 received no CRF but instead was fertigated twice daily with $250 \mathrm{~mL}$ of a complete nutrient solution including micronutrients (Bugbee, 2004), modified to contain $8 \mathrm{~mm} \mathrm{NH}_{4} \mathrm{NO}_{3}$, and adjusted to a $\mathrm{pH}$ of 5.5. Group 12 remained uninoculated and unfertilized, and was used for further confirmation that uninoculated plants remained unnodulated; no further data were collected from plants in this group. Plants in all treatments, except plants receiving $6 \mathrm{~g}$ of $\mathrm{CRF}$ and plants in groups 1 and 12, were inoculated at the base of the stem with $30 \mathrm{~g}$ of field soil collected from beneath plants of thinleaf alder (Alnus incana ssp. tenuifolia) located in Logan Canyon, UT, and confirmed in preliminary trials to contain Frankia compatible with seaside alder. Plants in the uninoculated 6.0-g CRF treatment received the manufacturer's recommended application rate of CRF for nursery stock in 6-inch-diameter standard round pots.

For the duration of the experiment, all plants except those receiving $\mathrm{NH}_{4} \mathrm{NO}_{3}$ in aqueous solution were irrigated twice daily with $250 \mathrm{~mL}$ of tap water $(\mathrm{pH} 7.3)$ to maintain the growing substrate near container capacity. Nitrate-N concentration of liquid leached from the bottom of containers was measured on days 1 , 14,28 , and 42 of the experiment for all plants receiving $0,2.0,6.0,8.0$, and $32.0 \mathrm{~g}$ of $\mathrm{CRF}$, and $8 \mathrm{~mm}$ $\mathrm{NH}_{4} \mathrm{NO}_{3}$, by using a $\mathrm{NO}_{3}-\mathrm{N}$ colorimeter test kit (\#3649 SC; Lamotte Co., Chestertown, MD). Leachate was collected from substrate by suspending plants in their containers above empty collection dishes during the second daily irrigation.

All plants were destructively harvested after $45 \mathrm{~d}$, and weights of leaf blades, stems, roots, and nodules were recorded separately after tissues had been dried for $3 \mathrm{~d}$ at $67^{\circ} \mathrm{C}$. Dried leaf blades were ground in a tissue homogenizer and analyzed for $\mathrm{N}$ content by using the Kjehldahl method (Bradstreet, 1954).

Data ANAlysis. Statistical analysis was performed using the SAS/ STAT software (version 9.1; SAS Institute, Cary, NC), and analysis of variance was performed using the general linear models procedure. Means separation analysis was performed using Fisher's least significant difference test. Levene's test was used to determine homogeneity of variances. Based on these results, a cubed-root transformation was used to achieve homogeneity of variance for nodule dry weight and nodule count before regression analyses. Analysis of $\mathrm{NO}_{3}-\mathrm{N}$ in the leachate from containers revealed that date of testing, treatment level, and their interaction were statistically significant; therefore, effects of CRF level, time, and their interaction were partitioned (Fig. 1). Linear regression analysis was used to predict the timing of $\mathrm{NO}_{3}-\mathrm{N}$ depletion from the leachate of CRF-treated plants; measurements from the first test date were excluded from this analysis to allow nutrient release from CRF to stabilize.

\section{Results}

Over the course of the 45-d experiment, plants of seaside alder that received less than $2 \mathrm{~g}$ of CRF did not grow significantly, and the leaves appeared smaller and lighter green than plants receiving greater amounts of fertilizer (Table 1, Fig. 2). The mean whole plant, shoot, and root dry weights of inoculated plants that received $2 \mathrm{~g}$ of CRF were $87 \%, 71 \%$, and $113 \%$, respectively, greater than those of plants harvested at the beginning of the experiment. These parameters in 2-g CRF-treated plants did not differ statistically from those of inoculated plants treated with $>4 \mathrm{~g}$ of CRF, or from uninoculated plants treated with the prescribed $6 \mathrm{~g}$ of CRF $(P<0.05)$ (Table 1$)$. No differences existed in root-to-shoot ratios among plants in any treatment and initial measurements taken from plants destructively harvested at the beginning of the experiment $(P<$ 0.05 ) (data not shown).

Quadratic regression functions best described the influence of CRF level on nodule dry weight (Fig. 3A) and nodule count (Fig. 3B); these parameters were maximal at $2 \mathrm{~g}$ of CRF. A quadratic regression function also best described the influence of CRF level on leaf $\mathrm{N}$ content, with maximal leaf $\mathrm{N}$ concentration above $16 \mathrm{~g}$ of CRF (Fig. 3C). Mean leaf N content of 2-g CRF-treated plants falls above the regression line and is similar to that of plants treated with CRF levels of $\geq 8 \mathrm{~g}$. Regression analyses of CRF level and shoot dry weight $\left(r^{2}=0.786 ; P=0.100\right)$, root dry weight $\left(r^{2}=0.0324 ; P=0.670\right)$, and plant dry weight $\left(\mathrm{r}^{2}=0.04 ; P=\right.$ 0.981 ) were not significant (data not shown).

Nitrate-N concentrations of leachate from tested containers were 
greatest after $14 \mathrm{~d}$ and decreased thereafter (Fig. 1). No differences in leachate $\mathrm{NO}_{3}-\mathrm{N}$ existed between 0 and 2-g CRF-treated plants on any test date $(P<0.10)$. After $14 \mathrm{~d}$, leachate $\mathrm{NO}_{3}-\mathrm{N}$ concentrations from 32-g CRF-treated plants were three times greater than that from $8-\mathrm{g}$ CRF-treated plants. Plants that received $8 \mathrm{~mm} \mathrm{NH}_{4} \mathrm{NO}_{3}$ from an aqueous solution had greater leaf $\mathrm{N}$ contents than plants in any other treatment (Table 1 ); $\mathrm{NO}_{3}-\mathrm{N}$ in leachate from these plants increased on each successive test date, with the greatest levels measured on day 42 of the experiment (data not shown). Linear regression revealed that levels of $\mathrm{NO}_{3}-\mathrm{N}$ would have been depleted from the leachate from 2-, 6-, 8-, and 32-g CRF-treated plants on days 52 $\left(\mathrm{r}^{2}=0.446 ; P=0.0065\right), 48\left(\mathrm{r}^{2}=\right.$ $0.470 ; P=0.0065), 54\left(\mathrm{r}^{2}=0.478\right.$; $P=0.0127)$, and $61\left(r^{2}=0.559 ; P=\right.$ $0.0011)$, respectively, with a mean depletion time of $54 \mathrm{~d}$ (data not shown). These analyses revealed that after $14 \mathrm{~d}$,
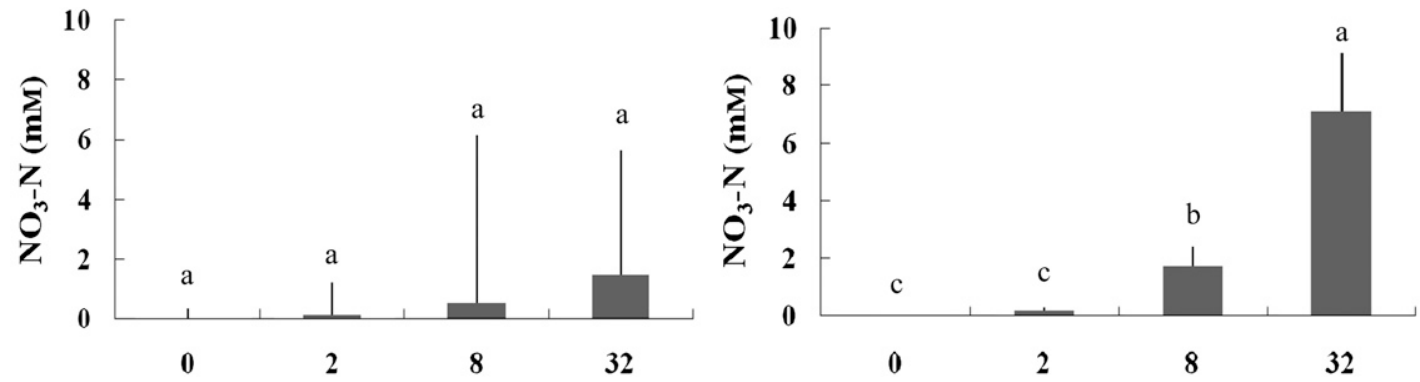

A

Controlled-release fertilizer (g)

$\mathrm{B}$

Controlled-release fertilizer (g)

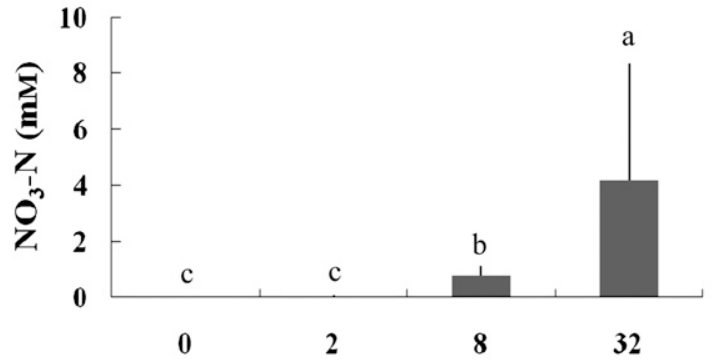

C

Controlled-release fertilizer (g)

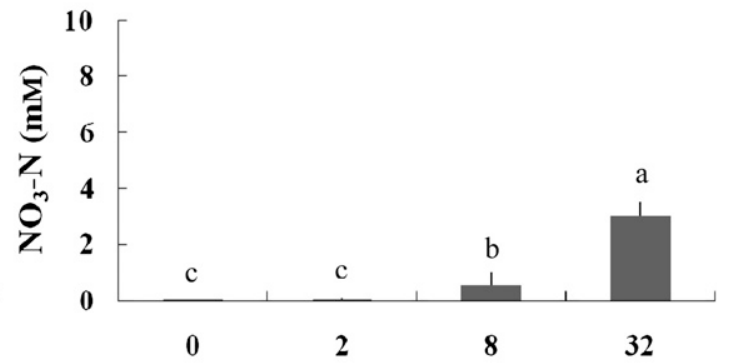

D

Controlled-release fertilizer (g)

Fig. 1. Nitrate-nitrogen $\left(\mathrm{NO}_{3}-\mathrm{N}\right)$ concentration in the leachate from pots containing soil-inoculated seaside alder seedlings treated with $0,2.0,8.0$, and $32.0 \mathrm{~g}$ of controlled-release fertilizer (CRF) after days 1 (A), 14 (B), 28 (C), and 42 (D) of a 45-d experiment. After $14 \mathrm{~d}, \mathrm{NO}_{3}-\mathrm{N}$ leached from pots containing seedlings treated with 8.0 or $32.0 \mathrm{~g}$ of CRF was significantly greater than $\mathrm{NO}_{3}-\mathrm{N}$ leached from pots containing seedlings treated with $2.0 \mathrm{~g}$ of CRF. Nitrate- $\mathrm{N}$ leached from the 2.0 -g CRFtreated pots was not different from those treated with $0 \mathrm{~g}$ of CRF $(\mathrm{n}=4)$. Means represented by each column with the same letter are similar at $P<0.10$ according to Fisher's least significant difference test; $1 \mathrm{~g}=0.0353 \mathrm{oz}$.

Table 1. Whole plant dry weight, number and dry weight of root nodules, leaf area and nitrogen (N) accumulation, and shoot and root dry weights of soil-inoculated and uninoculated seaside alder grown for $45 \mathrm{~d}$ with different levels of controlled-release fertilizer (CRF), or fertigated with a nutrient solution that contained $8.0 \mathrm{~mm}$ ammonium nitrate $\left(\mathrm{NH}_{4} \mathrm{NO}_{3}\right)(\mathrm{n}=4)$. Seedlings were watered twice daily to field capacity, and $\mathrm{N}$ fertilizer was provided three times per week for 8 weeks before treatments began 1 Aug. 2007.

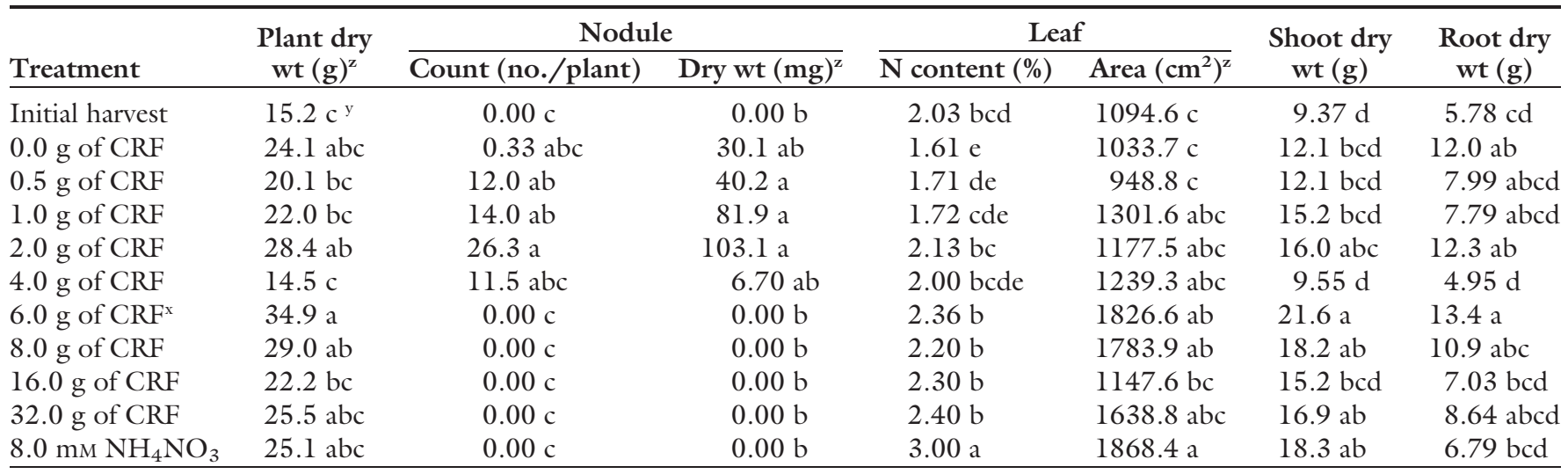

${ }^{\mathrm{z}} \mathrm{l} \mathrm{g}=0.0353 \mathrm{oz}, \mathrm{l} \mathrm{mg}=3.5274 \times 10^{-5} \mathrm{oz}, \mathrm{l} \mathrm{cm}{ }^{2}=0.1550 \mathrm{inch}^{2}$.

${ }^{\mathrm{y}}$ Means within each column followed by the same letter are similar at $P<0.05$ according to Fisher's least significant difference test.

${ }^{x}$ Uninoculated treatment. 


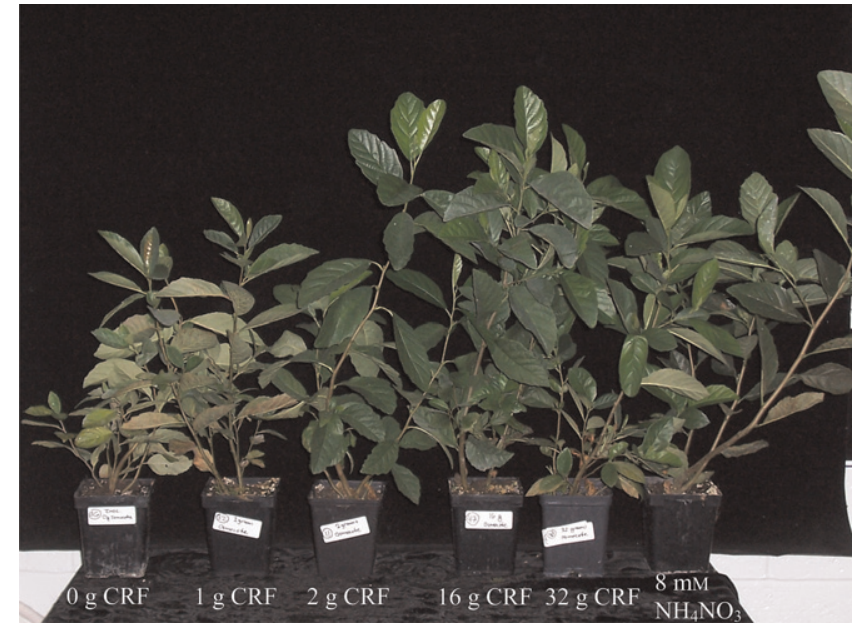

Fig. 2. Effects on growth of soil-inoculated and uninoculated seaside alder grown for $45 \mathrm{~d}$ with different levels of controlled-release fertilizer (CRF), or fertigated with a nutrient solution that contained $8.0 \mathrm{~mm}$ ammonium nitrate $\left(\mathrm{NH}_{4} \mathrm{NO}_{3}\right)$ $(\mathrm{n}=4)$. Inoculated seaside alder seedlings treated with $<1.0 \mathrm{~g}$ of CRF were stunted and chlorotic, whereas inoculated seedlings treated with $\geq 8.0 \mathrm{~g}$ of CRF were lush and vigorous. Inoculated seedlings treated with only $2.0 \mathrm{~g}$ of CRF were similar in size and leaf color to inoculated plants treated with higher levels of nitrogen, and to uninoculated plants treated with the manufacturer-prescribed $6.0 \mathrm{~g}$ of CRF (not shown); $1 \mathrm{~g}=\mathbf{0 . 0 3 5 3} \mathrm{oz}$.

$\mathrm{NO}_{3}-\mathrm{N}$ levels in the CRF-treated plants decreased in a linear fashion until the end of the experiment.

\section{Discussion}

Our results demonstrate that levels of $\mathrm{N}$ and other nutrients provided by CRF at a rate of $2 \mathrm{~g}$ per container enhance nodulation and growth of seaside alder seedlings over a 45 -d period, while minimizing leaching of $\mathrm{NO}_{3}-\mathrm{N}$ from containers. Inoculated plants treated with $2 \mathrm{~g}$ of CRF formed the greatest number and weight of nodules, and exhibited growth and $\mathrm{N}$ accumulation patterns similar to or greater than inoculated plants treated with higher levels of CRF, and uninoculated plants treated with the prescribed rate of $6 \mathrm{~g}$ of CRF (Table 1). Nodulation was nearly or completely prevented by CRF applications of $\geq 4 \mathrm{~g}$, and by fertigation with a solution containing $8 \mathrm{~mm}$ $\mathrm{NH}_{4} \mathrm{NO}_{3}$.

Nodulation patterns of plants in this experiment were consistent with those reported in previous work with actinorhizal species. Nodulation was prevented by the application of $6 \mathrm{~mm}$ $\mathrm{NH}_{4} \mathrm{NO}_{3}$ in mexican cliffrose (Purshia mexicana) and antelope bitterbrush (Purshia tridentata) grown in a greenhouse (Righetti et al., 1986). Arnone et al. (1994) showed that nodule formation was inhibited in river sheoak (Casuarina cunninghamiana) plant roots when exposed to $3 \mathrm{~mm} \mathrm{NO}_{3}$, but nodules were observed on all root systems exposed to $0.05 \mathrm{~mm} \mathrm{NO}_{3}$. Kohls and Baker (1989) observed inhibition of nodulation at $2 \mathrm{~mm} \mathrm{NH}_{4} \mathrm{NO}_{3}$ in european alder (Alnus glutinosa).

Laws and Graves (2005) found that nodule formation and plant vigor was maintained in plants of seaside alder that received between 0.5 and $2 \mathrm{~mm} \mathrm{NH}_{4} \mathrm{NO}_{3}$ from Hoagland solution modified to provide different $\mathrm{NH}_{4} \mathrm{NO}_{3}$ concentrations with a constant level of phosphorus (P), potassium $(\mathrm{K})$, and micronutrients; plants were inhibited at levels $\geq 4 \mathrm{~mm}$ $\mathrm{NH}_{4} \mathrm{NO}_{3}$. In our work, nodulation in seaside alder declined at $4 \mathrm{~g}$ of CRF and was completely inhibited at $8 \mathrm{~g}$ of CRF. In equivalent terms, nodulation in our experiment was completely prevented at daily $\mathrm{N}$ levels of $1.6 \mathrm{mmol}$; in experiments by Laws and Graves (2005), nodulation was completely prevented at daily $\mathrm{N}$ levels of $2.4 \mathrm{mmol}$ (Table 2). Nitrogen was provided in the form of $\mathrm{NH}_{4} \mathrm{NO}_{3}$ in both cases, thus the form of $\mathrm{N}$ did not account for differences in tolerance to daily $\mathrm{N}$.

One explanation for this discrepancy in nodule-inhibition levels of $\mathrm{N}$ in seaside alder is that there may have been variation in the daily release rate of CRF in our experiment that could have resulted in periods of time in which daily $\mathrm{N}$ levels were similar to those of Laws and Graves (2005). Others have noted variation over time in patterns of nutrient release from CRF (Cabrera, 1997; Huett and Gogel, 2000). Nutrient release rate is known to be influenced by many factors, including temperature (Engelsjord et al., 1997; Huett and Gogel, 2000; Husby et al., 2003). In our study, irrigation of plants twice daily was a factor in the increased release rate and shortened the useful life of applied CRF. Twice-daily irrigation was needed to keep plants free from drought stress in the dry climate of Utah.

A second possible explanation for the discrepancy in nodule-inhibition levels of $\mathrm{N}$ in seaside alder is the influence of substrate composition on nutrient retention and cation exchange capacity (CEC). Substrates containing peatmoss, vermiculite, or other components with high CEC potentially could delay or discourage nodule formation on inoculated plant roots at lower levels of $\mathrm{N}$ because applied $\mathrm{N}$ might remain in the root zone longer, and build up over time to the point where it could become inhibitory. Laws and Graves (2005) used coarse perlite, a substrate with a relatively low CEC. We used a substrate consisting of 1 sphagnum peatmoss: 1 perlite (by volume), which has a higher CEC than perlite alone.

Alternately, our use of a substrate with a higher CEC could have resulted in greater uptake and storage of $\mathrm{N}$ in seaside alder seedlings before soil inoculation. Thomas and Berry (1989) demonstrated that the inhibitory effect on nodulation of $\mathrm{N}$ provided before inoculation of carmel ceanothus (Ceanothus griseus var. horizontalis) persisted after $\mathrm{N}$ fertilization was withdrawn, and that the level of $\mathrm{N}$ provided preinoculation differentially affected the number of nodules formed on plants after inoculation. This suggests that $\mathrm{N}$ taken up and stored by the plant can have a later inhibitory effect on nodule number. The potentially greater amounts of $\mathrm{N}$ taken up and stored in our plants as a result of growth in a substrate with higher CEC could have resulted in inhibition of nodulation at lower 

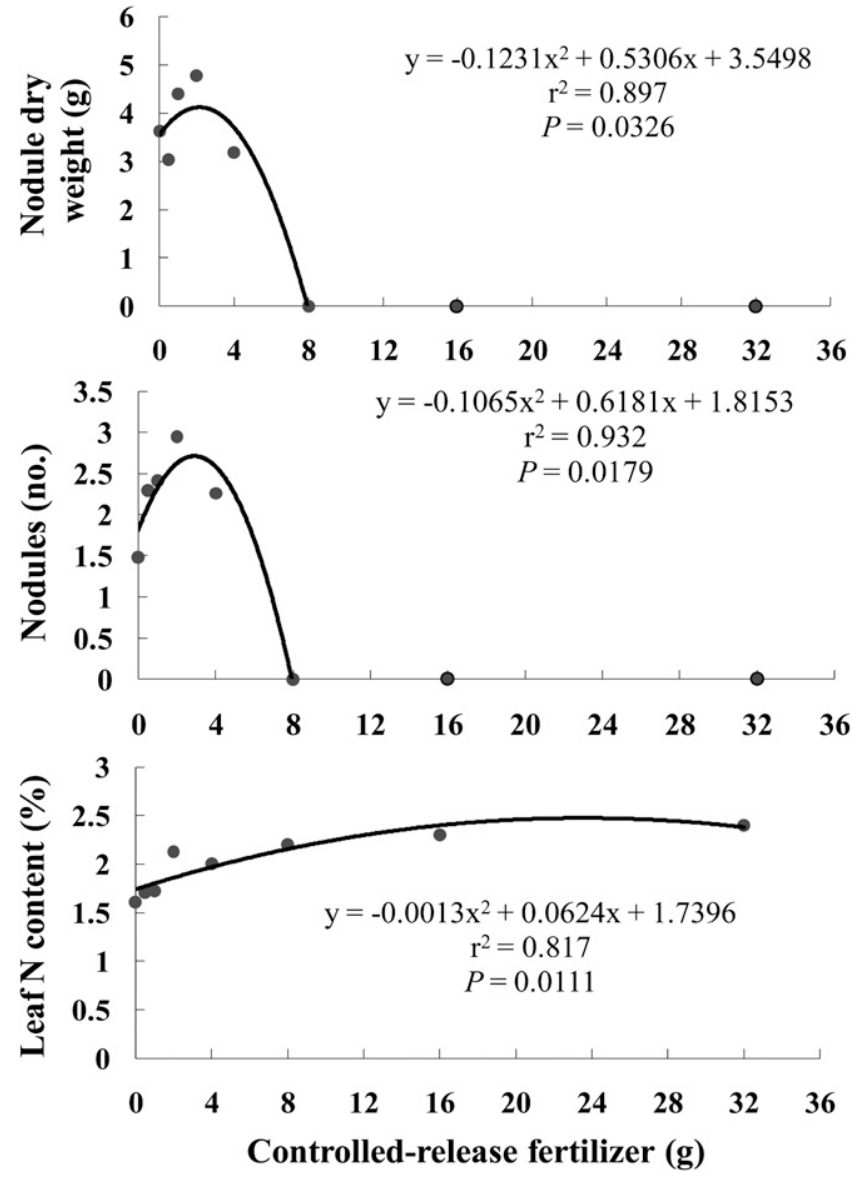

Fig. 3. Regression analyses of controlled-release fertilizer (CRF) level on nodule dry weight (A), nodule count (B), and leaf nitrogen (N) content (C) of soil-inoculated seaside alder grown for $\mathbf{4 5} \mathrm{d}$ with different levels of controlled-release fertilizer $(C R F)(n=4)$. Quadratic functions best described these relationships at CRF levels from 0 to $8.0 \mathrm{~g}$. To meet the requirement for homogeneity of variance, nodule dry weight and nodule count were analyzed and are displayed as cubed-root transformed data; $1 \mathrm{~g}=0.0353 \mathrm{oz}$.

Table 2. Comparison of theoretical daily amounts of nitrogen $(\mathrm{N})$ received by soil-inoculated and uninoculated seaside alder grown for $\mathbf{4 5} \mathrm{d}$ with different levels of controlled-release fertilizer (CRF), or fertigated with a nutrient solution that contained $8.0 \mathrm{~mm}$ ammonium nitrate $\left(\mathrm{NH}_{4} \mathrm{NO}_{3}\right)(\mathrm{n}=4)$ with that received by seaside alder as reported in work by Laws and Graves (2005). Asterisks represent $\mathrm{N}$ levels at which complete inhibition of nodulation was observed in each study.

\begin{tabular}{|c|c|c|c|}
\hline Treatment & $\begin{array}{c}\text { Mean N } \\
\left(\mathrm{mmol}^{\left.-\mathrm{d}^{-1}\right)^{\mathrm{z}}}\right.\end{array}$ & $\begin{array}{l}\text { Laws and Graves }(2005) \\
\text { treatment }\left(\mathrm{mM} \mathrm{NH}_{4} \mathrm{NO}_{3}\right)^{\mathrm{y}}\end{array}$ & $\begin{array}{c}\text { Mean N } \\
\left(\mathrm{mmol}^{-\mathrm{d}^{-1}}\right)\end{array}$ \\
\hline $0.5 \mathrm{~g}$ of $\mathrm{CRF}^{\mathrm{x}}$ & 0.1 & 0.25 & 0.15 \\
\hline $1.0 \mathrm{~g}$ of CRF & 0.2 & 0.50 & 0.30 \\
\hline $2.0 \mathrm{~g}$ of $\mathrm{CRF}$ & 0.4 & 0.75 & 0.45 \\
\hline $4.0 \mathrm{~g}$ of CRF & 0.8 & 1.0 & 0.60 \\
\hline $6.0 \mathrm{~g}$ of $\mathrm{CRF}^{\mathrm{w}}$ & 1.1 & 1.25 & 0.75 \\
\hline $8.0 \mathrm{~g}$ of CRF & $1.6^{*}$ & 1.5 & 0.90 \\
\hline $16.0 \mathrm{~g}$ of CRF & 3.2 & 2.0 & 1.2 \\
\hline $32.0 \mathrm{~g}$ of CRF & 6.3 & 4.0 & $2.4^{*}$ \\
\hline $8.0 \mathrm{mM} \mathrm{NH}_{4} \mathrm{NO}_{3}^{\mathrm{v}}$ & 8.0 & 8.0 & 4.8 \\
\hline
\end{tabular}

${ }^{\mathrm{z}}$ Assuming a mean 54 -d release rate as per linear regression analysis of nitrate- $\mathrm{N}$ leached from containers.

'Plants received $300 \mathrm{~mL}(10.14 \mathrm{fl} \mathrm{oz})$ of nutrient solution once daily.

${ }^{\mathrm{x}} \mathrm{lg}=0.0353 \mathrm{oz}$.

${ }^{w}$ Uninoculated treatment.

vPlants received $250 \mathrm{~mL}(8.45 \mathrm{fl} \mathrm{oz})$ of nutrient solution twice daily. concentrations of applied $\mathrm{N}$ during our experiment than that observed by Laws and Graves (2005).

A third explanation for the discrepancy in inhibition levels of $\mathrm{N}$ in seaside alder is the possible influence of other nutrients provided in the CRF, which we could not control at high CRF levels. Although we are unaware of any study reporting inhibition of root nodulation in actinorhizal plants by nutrients other than $\mathrm{N}$, it is feasible that some micronutrients provided by higher levels of CRF could have been inhibitory, although we observed no negative effects of high levels of CRF on plant growth parameters (Table 1 ). We did, however, observe growth and nodulation inhibition at CRF levels lower than $2 \mathrm{~g}$ and at $4 \mathrm{~g}$, probably due to lack of supporting nutrients. In addition, at $4 \mathrm{~g}$ of CRF, it is likely plants were exposed to enough $\mathrm{N}$ to inhibit nodulation, but not enough to meet the growth needs of plants.

Research performed by others has shown that nutrients other than $\mathrm{N}$ can also influence nodule formation in actinorhizal species. Valverde et al. (2002) observed that nodule dry weight was maximal when plants of chacay (Discaria trinervis) were treated with $\mathrm{P}$ at concentrations between 100 and $1000 \mu \mathrm{M}$ compared with plants receiving less P. Micronutrients such as iron $(\mathrm{Fe})$ and molybdenum (Mo) may also influence nodule function (Huss-Danell, 1997). In our study, regression analysis revealed that nodule dry weight and nodule count were maximal in plants treated with $2 \mathrm{~g}$ of CRF (Fig. 3, A and B). We hypothesize that the $2 \mathrm{~g}$ of CRF applied in our study provided just enough of all the nutrients to support nodule function without levels of $\mathrm{N}$ that would inhibit nodule formation.

Although we did not perform N fixation assays, strong evidence supports the conclusion that $\mathrm{N}$ fixation was occurring in nodulated plants in our study because at CRF levels less than the prescribed rate, leaf $\mathrm{N}$ content rose as nodule count and dry weight increased (Table 1). Further evidence can be seen in Fig. 3C; leaf N content of plants in the 2-g CRF treatment is above the regression line and is similar to $\mathrm{N}$ content of plants that received $\geq 8$ $\mathrm{g}$ of CRF.

The presence of nodules on nursery plants could reduce $\mathrm{N}$ fertilizer use and result in more efficient use of 
applied N. The use of CRF for fertilization may reduce $\mathrm{NO}_{3}-\mathrm{N}$ leaching from containerized nursery crops. Our study demonstrates that vigorous nodulated plants of seaside alder can be produced by using CRF rates below that prescribed by the manufacturer, with minimal leaching of $\mathrm{NO}_{3}-\mathrm{N}$. Seaside alder has potential for use in sustainable landscapes and can be produced readily in a nodulated form by growers. While individual growers will need to experiment to optimize lowinput production of seaside alder and other $\mathrm{N}$-fixing species, our results demonstrate that sustainable, lowinput production of $\mathrm{N}$-fixing species is possible, and that these taxa deserve a place high on the list of sustainable nursery crops. Future work should test the hypothesis that nodulated plants will have increased survival upon installation in the landscape. Nitrate leaching from nodulated plants in the landscape also should be tested because no data are available on optimal levels of $\mathrm{N}$ fertilization of nodulated landscape plants.

\section{Literature cited}

Arnone, J.A., S.J. Kohls, and D.D. Baker. 1994. Nitrate effects on nodulation and nitrogenase activity of actinorhizal Casuarina studied in split-root systems. Soil Biol. Biochem. 26:599-606.

Berry, A.M. and J.G. Torrey. 1985. Seed germination, seedling inoculation and establishment of Alnus spp. in containers in greenhouse trials. Plant Soil 87:161-173.

Bradstreet, R.B. 1954. Kjeldahl method for organic nitrogen. Anal. Chem. 26: 185-187.

Bugbee, B. 2004. Nutrient management in recirculating hydroponic culture. Acta Hort. 648:99-112.

Cabrera, R.I. 1997. Comparative evaluation of nitrogen release patterns from controlled-release fertilizers by nitrogen leaching analysis. HortScience 32:669673.

Colangelo, D.J. and M.H. Brand. 2001. Nitrate leaching beneath a containerized nursery crop receiving trickle or overhead irrigation. J. Environ. Qual. 30:15641574 .

Engelsjord, M.E., O. Fostad, and B.R. Singh. 1997. Effects of temperature on nutrient release from slow-release fertilizers. Nutr. Cycl. Agroecosyst. 46:179187.

Gentili, F. and K. Huss-Danell. 2003. Local and systemic effects of phosphorus and nitrogen on nodulation and nodule function in Alnus incana. J. Expt. Bot. 54: 2757-2767.

Graves, W.R. and J.A. Schrader. 2004. 'September Sun' seaside alder, an autumn-blooming shrub native to North America. HortScience 39:438-439.

Hansen, E.A. and J.O. Dawson. 1982. Effect of Alnus glutinosa on hybrid Populus height growth in a short-rotation intensively cultured plantation. For. Sci. 28:49-59.

Huett, D.O. and B.J. Gogel. 2000. Longevities of nitrogen, phosphorus and potassium release patterns of polymer-coated controlled-release fertilizer at $30^{\circ}$ and $40^{\circ}$ C. Commun. Soil Sci. Plant Anal. 31: 959-973.

Husby, C.E., A.X. Niemiera, J.R. Harris, and R.D. Wright. 2003. Influence of diurnal temperature on three polymercoated fertilizers. HortScience 38:387389.

Huss-Danell, K. 1997. Tansley review no. 93. Actinorhizal symbioses and their $\mathrm{N}_{2}$ fixation. New Phytol. 136:375-405.

Kratsch, H.A. 2008. Alnus maritima ssp. oklahomensis performance in non-irrigated landscapes in the Intermountain West. J. Environ. Hort. 26:229-234.

Kohls, S.J. and D.D. Baker. 1989. Effects of substrate nitrate concentration on symbiotic nodule formation in actinorhizal plants. Plant Soil 118:171-179.
Laws, M.T. and W.R. Graves. 2005. Nitrogen inhibits nodulation and reversibly suppresses nitrogen fixation in nodules of Alnus maritina. J. Amer. Soc. Hort. Sci. 130:496-499.

Martin, K.J., N.J. Posavatz, and D.D. Myrold. 2003. Nodulation potential of soils from red alder stands covering a wide age range. Plant Soil 254:187-192.

Paschke, M.W. 1997. Actinorhizal plants in rangelands of the western United States. J. Range Manage. 50:62-72.

Righetti, T.L., C.H. Chard, and R.A. Backhaus. 1986. Soil and environmental factors related to nodulation in Cowania and Purshia. Plant Soil 91:147-160.

Schrader, J.A. and W.R. Graves. 2000a. Propagation of Alnus maritima from softwood cuttings. HortScience 35:293295.

Schrader, J.A. and W.R. Graves. 2000b. Seed germination and seedling growth of Alnus maritima from its three disjunct populations. J. Amer. Soc. Hort. Sci. 125: 128-134.

Sellstedt, A. and K. Huss-Danell. 1986. Biomass production and nitrogen utilization by Alnus incana when grown on $\mathrm{N}_{2}$ or $\mathrm{NH}_{4}{ }^{+}$made available at the same rate. Planta 167:387-394.

Stibolt, V.M. 1978. The ecology and systematics of Alnus maritima Muhl. ex Nutt. (Betulaceae). MS Thesis, Univ. Maryland, College Park.

Thomas, K.A. and A.M. Berry. 1989. Effects of continuous nitrogen application and nitrogen preconditioning on nodulation and growth of Ceanothus griseus var horizontalis. Plant Soil 118:181-187.

Urbano, C.C. 1989. The environmental debate: An industry issue. Amer. Nurseryman 169:69-73, 76-79, 81, 83, 85 .

Valverde, C., A. Ferrari, and L.G. Wall. 2002. Phosphorus and the regulation of nodulation in the actinorhizal symbiosis between Discaria trinervis (Rhamnaceae) and Frankia BCU110501. New Phytol. $153: 43-52$. 